\title{
C.S. パースの探究の理論に基づく設計プロセスのモデルの構築 CONSTRUCTING A MODEL OF DESIGN PROCESS BASED ON C.S. PEIRCE'S THEORY OF INQUIRY
}

\author{
山口＼cjkstart純*, 門内輝 行** \\ Jun YAMAGUCHI and Teruyuki MONNAI
}

\begin{abstract}
Studies on architectural design process have been strongly influenced by epistemologies. Rationalism and empiricism originated a view of design as a rational problem-solving. The defect of this view of design has its roots in a foundationalistic tendency of these epistemologies. C. S. Peirce's pragmatism provides an alternative, fallibilistic epistemology. This paper aims at constructing a model of design process based on Peirce's theory of inquiry. His theory of inquiry is reinterpreted in terms of his category theory. Design process is modeled as an inquiry consisting of abduction, deduction, and induction. Cases of design process are analyzed by this model.
\end{abstract}

Keywords : Design Process, Inquiry, Abduction, C.S. Peirce, Pragmatism

設計プロセス，探究，アブダクション， C. S. パース，プラグマティズム

\section{1.はじめに}

建築の設計プロセスの研究は、「認識論」（epistemology）に強く 影響されてきた。設計は「分析」(analysis) と「総合」（synthesis） による「合理的問題解決」(rational problem solving) であると見 なされてきたが、この見方は、「合理主義」(rationalism) 並びに「経 験主義」（empiricism）（そして特にその一種である「実証主義」 (positivism)）という認識論の伝統に由来する 1)。後に述べるよう に「合理的問題解決」としての設計という見方は今日の建築設計の 問題に対して必ずしも妥当なアプローチを与えない。

C. S. パース（C. S. Peirce）が提唱した「プラグマティズム」 (pragmatism) は代替的な認識論であり、合理主義と経験主義（と 実証主義）に対する反論を含む。合理主義は原理を、経験主義（と 実証主義）は経験を、「直観」（intuition）すなわち無媒介的認識に よって得られた知識の基盤であるとみなす。原理ないし経験を知識 の絶対的基盤とみな寸限りにおいて、これらの認識論は「基礎付け 主義」（foundationalism）を採っている。これに対しパースは、す べての認識は「習慣」（habit）に媒介されているとみなす。したが って知識に絶対的な基盤はなく、われわれは常に謬りうる。この主 張を「可謬主義」(fallibilism) という。こうしてパースのプラグマ ティズムにおいては、絶対的な基盤からの知識の導出ではなく、「信 念」(belief）つまり行動習慣の形成過程としての「探究」（inquiry） が、中心的主題となる 2)。本研究はこのパースの探究の理論に基づ いて、可謬主義的な設計プロセスのモデルを構築する。
2. 研究の背景、目的と方法

\section{1 研究の背景}

\section{1.1 合理的問題解決としての設計観}

1960 年代に建築の設計プロセスの研究が本格的に開始された当 初、その主な関心は設計プロセスを合理化、効率化することに置か れていた ${ }^{3)}$ 。そのために設計プロセスを「合理的問題解決」として 理解することが試みられた。合理的問題解決と呼ぶのは、所与の（固 定的なものと見なしうる）問題からの、分析と総合といった合理的 な手続きによる、解決の導出と確定である。この見方は決定的定式 化が可能な工学的問題に対しては成果を発揮した。

\subsection{2 合理的問題解決としての設計観への批判}

しかしこの見方には批判や反省が与えられている。建築設計の問 題は通常、社会的性質を帯びる。特に今日の建築設計は地域コミュ ニティーのエンパワメントといった高度に社会的な問題に関わる。

設計理論家の H.リッテル（H. Rittel）は、組織やコミュニティーに 関わる設計の問題が、決定的な定式化を与えることのできない、「意 地悪な問題」（wicked problem）であることを指摘し、決定的な定 式化のできる「おとなしい問題」（tame problem）と対比させた 4)。 合理的問題解決として設計を見な寸アプローチが有効なのは、「お なしい問題」に対してのみであり、「意地悪な問題」に対してではな い注 1)。意地悪な問題」においては問題と解決が相互依存的であり、 問題を定式化することが、解決を与えることになる。

リッテルと並び、D. A . ショーン（D.A. Schön）は合理的問題

\footnotetext{
* 京都大学大学院工学研究科 博士後期課程 $\cdot$ 工修

** 京都大学大学院工学研究科 教授. 工博 
解決としての設計観に異議を唱えた代表的な研究者の一人である。 彼によればこの設計観は実証主義の影響に支配され、実践を理論の 応用であると見な寸点において妥当でない。なぜなら専門家の実践 において、思考と行為は分かちがたく結びついているからである5。

\subsection{3 代替的設計観}

こうして、合理的問題解決としての設計観に代わる、代替的設計 観が提唱されるようになった。リッテルは設計を「論争的プロセス」 (argumentative process)4) と見なすべきだとした。ショーンは設計 を「行為の中の反省」（reflection-in-action）を伴う「設計の状況と の対話(conversation)」5)であるとした。他に、「問題と解決の間の 交渉(negotiation)」6)、「つくる」というより「育てる」7)ことなの だといった設計観が提唱されている。これらの設計観は、設計の問 題を、固定的なものではなく、設計プロセスの中で（解決を与えて いく中で）変化していくものとして見なす。

特にショーンの示した「状況との対話」としての設計という見方 は代表的な代替的設計観であり重要である。その概要は次のような ものである。設計者はスケッチや模型などを含む設計の「状況」に 働きかける。この行為はしばしば状況に意図せぬ帰結をもたらす。 設計者はこの帰結、つまり状況の「応答」(back- talk) を聞き取り、 場合によっては問題を再定義しつつさらに状況へと次の行為を返す。 このプロセスの中で、設計者は状況の捉え方つまり「フレーム」 (frame) を反省し再設定しうる8)。こうして設計者の意図、問題 設定やそれを解決するとはどういうことなのかは、設計のプロセス の中で変化していく。

K. ドルスト (K. Dorst) らは合理主義問題解決としての設計観と ショーンの設計観を対比し、前者は問題と戦略が明確な場合に適し ているが、戦略が不明確なコンセプト段階については後者が適して いると結論している ${ }^{9)}$ 。建築設計の問題は、「おとなしい問題」の傾 向が強ければ合理主義的問題解決としての設計という見方も妥当で あるが、すくなくともコンセプト段階においては、「意地悪な問題」 の傾向が優勢であり、従って代替的な設計観が必要されると言える。

\subsection{4 設計観と認識論}

二つの設計観は以下のように認識論と関係している。合理的問題 解決としての設計観は、認識論としては合理主義と経験主義（特に 実証主義）の影響下にあり、これらの認識論が持つ基礎付け主義的 傾向に由来する欠点を持っている。つまりこれらの認識論が知識を 絶対的な基盤に基礎付けようとするのと同じように、この設計観は 解決としてのデザインを問題という基盤に基礎付けようとする。そ のために問題を固定的なものとして想定してしまうのである。しか し「意地悪な問題」を固定的なものとして見なすことはできない。 一方、パースは、 1 章で述べたように、基礎付け主義を退け、可 謬主義を主張した。彼の探究の理論は、絶対的基盤からの知識の導 出ではなく、習慣の進化を主題としている。これは、解決と問題は 同時に明確化するものだという、「意地悪な問題」に適合した代替的 な設計観に対応する認識論だと考えられる。

\section{2 研究の目的と方法}

本論の目的は、代替的設計観(設計の問題を所与のものではなく、 設計プロセスの中で変化していくものとして見な寸設計観）に対応 するような設計プロセスのモデルを、パースの探究の理論をもとに 構築することである。
研究の方法としてはまず、パースの探究の理論を、特に彼の哲学 の核心にあるカテゴリー論に関係づけて解釈寸る。これを基に設計 プロセスのモデルを構築する。構築されたモデルをもとに、設計実 験で得られた設計プロセスの事例を分析する。本論の研究の方法も また、実証主義ではなくプラグマティズムである。つまり、事例か らの一般化によってモデルを構築しようとするのではなく、パース の探究の理論が設計プロセスのモデルを与えるという仮説をもとに モデルを構築し、次にこのモデルを事例分析に用いて設計プロセス を理解する観点を見いだすことで、このモデルの意味を検討する。

\section{3 研究の位置づけ}

本研究は、認識論的な反省を伴った設計プロセスのモデル構築へ のアプローチという文脈の中に位置づけられる。これまで多くの設 計プロセスのモデルが提案されてきたが、その認識論的背景に意識 的である場合は少ない。合理的問題解決としての設計観の中で、「分 析／総合」を基本的な要素とした数々のモデルが提案されてきたが 6)、それらは、ショーンや G. バムフォード（G. Bamford）が指摘 するように、(暗黙的であれ）特に実証主義に影響されていた ${ }^{5)}$, 1)。 それに対して本論は先述したような代替的設計観に対応するモデ ルを構築しょうとするものである。ショーンはパースに始まり J. デ ューイ (J. Dewey) を経たプラグマティズムの流れに属しているが、 パースの探究の理論を明確に採用してはいない。可謬主義的認識論 としては、プラグマティズムの他に、K. ポパー（K. Popper）の反 証主義や、その展開である I.ラカトシュ（I. Lakatos）のリサーチ プログラム論がある。これらは冒険的な仮説の推測を伴う試行錯誤 として科学的探究を理解する。バムフォードは、設計に関する「分 析／総合」モデルとの対比において、「推測（conjecture）／分析」 モデルを評価し、後者をポパーの影響に帰している 1)。 M. ブロー ン (M. Brawne) はポパーによる科学的探究のモデルを適用した「問

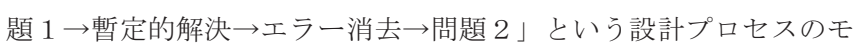
デルを提示している 10)。S. アンダーソン（S. Anderson）はラカト シュのリサーチプログラム論を建築設計の分析に適用している ${ }^{11) 。}$

しかしポパーの理論は、仮説の発見の文脈と正当化の文脈という 区別において、正当化の文脈のみを哲学的反省の対象としたので、 仮説がどのようにして生成されるかについては、示唆するところが 少ない。この点で本論が注目するパースの探究の理論は「アブダク ション」という推論形式に従うものとして仮説生成を論じている。

これまでにもアブダクションに注目した設計プロセスの研究はな

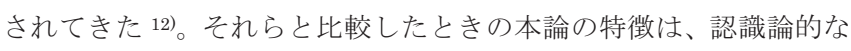
側面からパースの探究の理論を検討しており、そこでアブダクショ ンの理論を、探究の理論の一部として、パースのカテゴリー論との 連関の中で把握している点である。

\section{3 . パースの探究の理論}

パースの提唱したプラグマティズムとは、概念の意味とはそれが 実践的行為一及ぼすと考えられる帰結であるという考えである。し たがってこの立場からは、将来の実践的行為に影響を及ぼす可能性 のある観念は、意味を持ちうる。したがって科学的探究において、 仮説はそれが事実を説明するかもしれないというだけの理由で採用 されうる。この謬りうる仮説生成の推論形式が「アブダクション」 (abduction) と呼ばれる。パースは、よく知られた「演繹」 
(deduction) と「帰納」（induction）にアブダクションを加えた三 つが、これ以上還元できない推論形式として存在しており、新しい 観念の生成はアブダクションに従うと主張した (CP 2.96) 注2）,13), 14), 15), 16)。新しい観念の生成が推論だということの意味は、それが無 媒介的認識という意味での「直観」(intuition)ではなく、法則に媒 介されたプロセスであるということである。しかしその法則とは固 定的で絶対的な規則ではなく、進化する「習慣」（habit）である。 「探究」(inquiry) とは「信念」（belief）の形成プロセスである。 信念とは「人がそれに基づいて行動する用意のあるところのもの」 (CP 5.12) であり、一般的な意味では、「習慣」である (CP 2.148)。 以下ではアブダクションの理論を軸に、彼の探究の理論を説明する。

\section{1 アブダクションの理論}

パースのアブダクション理論は前期と後期に分けて説明できる 17), 18), 19)。探究に明示的に関係付けられるのは後期からである。しか し後に述べるカテゴリー論との関係を説明するために、前期理論に も触れねばならない。前期理論において推論の三形式 (演繹、帰納、 アブダクション）は、三段論法の三つの命題（大前提、小前提、結 論）の入れ替えによって定義される（CP 2.623）。パースは、大前 提、小前提、結論をそれぞれ、法則 (rule)、事例 (case)、結果 (result) を表すものとして見なし、推論の三形式を次のように定義した。

\section{演繹：法則と事例から結果を導く推論 \\ 帰納：事例と結果から法則を導く推論 アブダクション：結果と法則から事例を導く推論}

以下が例である。

\section{演繹}

$$
\begin{aligned}
& \text { この袋の豆はすべて白い (規則) } \\
& \text { これらの豆はこの袋の豆である (事例) } \\
& \text { ゆえに、これらの豆は白い (結果) }
\end{aligned}
$$

\section{帰納}

これらの豆はこの袋の豆である (事例)

これらの豆は白い (結果)

ゆえに、この袋の豆はすべて白い (規則)

\section{アブダクション}

これらの豆は白い (結果)

この袋の豆はすべて白い (規則)

ゆえに、これらの豆はこの袋の豆である (事例)

図式化すると図 1 のようになる。事例、法則、結果という三項の 関係の入れ替えとして推論の三形式が定義されるのである。

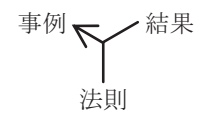

アブダクション

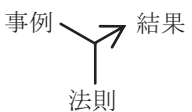

演繹

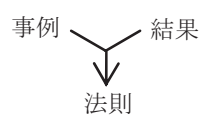

帰納
図 1 パースの前期理論における推論の三形式

後期理論では、必ずしも三段論法の形式に拘らなくなり（CP 2 . 102)、むしろ三つの推論形式は次のように探究の三つの段階として 捉え直される。(CP 7. 202-206, 6. 469-472)

アブダクション（探究の第一段階）: 仮説を生成する

演繹（探究の第二段階）: 仮説から予想を導く

帰納（探究の第三段階）：予想と事実を照合して仮説を検証する
またアブダクションは次のように再定式化されている。

驚くべき事実 Cが発見される。

しかしもし A が真であればCは当然のことであろう。

したがってA が真であると考える理由がある。(CP 5.189)

例えば内陸で魚の化石が見つかる（その場所がずっと陸地であっ たと考えている人は驚くだろう)。しかしもしその場所が海であった とすれば、魚の化石が見つかるのは当然のことだろう。こうして、 その場所が海であったという仮説が生まれる。

同様に後の探究の段階に当てはめれば次のようになる。演繹によ って、もしこの仮説が正しければ他の魚や藻や貝などの化石も見つ かるだろうという予想が導かれる。帰納は、実際の発掘作業を経て、 この予想を事実と照合し仮説の妥当性を検証する。

\section{2 探究の理論についての解釈}

\section{2.1 驚くべき事実の認識論的位置付け}

後期定式化における「驚くべき事実」（surprising fact）とは、パ ースのプラグマティズムにおいて、探究が始まる契機として見なさ れるものを示している。探究は習慣形成のプロセスであり、「疑念」 (doubt) つまり習慣の欠乏から始まる。そして「真正の疑念とは、 常に外的な由来をもち、通常は驚き (surprise) から来る」(CP 5.443)。 驚くべき事実とは疑念をもたらす外的な要因である。

驚くべき事実は、合理主義における知識の基盤としての明証的な

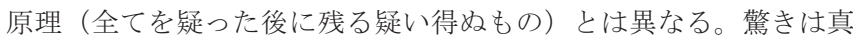
正の疑念をもたらすが、自らの意志で信念を疑問に付すことによっ ては真正の疑念はもたらされないからである（CP 5.416-417）。

一方で、驚くべき事実は、経験主義（と実証主義）における知識 の基盤としての感覚与件(解勫以前にある直接的経験) とも異なる。 事実とは「知覚判断」（perceptual judgment）の結果であるが、パ ースによれば知覚判断はアブダクションの極端な形式だからである (CP 5.151, 183)。つまり事実とは、無垢な観察ではなく、それじ たい寸でに習慣に媒介された解釈の結果なのである。

我々は、「寸でに形成された莫大な量の認知を負わされている」状 態（CP 5.416）、つまり習慣を伴った状態からしか探究を始めるこ とができない。驚くべき事実とは、習慣を破壊することによってア ブダクションの契機（すなわち探究の始まる契機）となる外的要因 であると同時に、それじたい既存の習慣に媒介されているのである。

\section{2.2 探究の循環による習慣の進化}

驚くべき事実が習慣を破壊するのは、それが習慣に基づく予想と 異なるからである注3)。予想は先行寸る仮説と習慣からの演繹によっ て導かれていると考えられる。したがって探究には循環的な構造が あると言える。つまり演繹は既存の仮説と習慣から予想を導く。次 に帰納において事実が予想と一致するときは仮説の妥当性が得られ る。しかし、これが一致しないときは驚きが生じ、それを契機とし たアブダクションによって新しい仮説が生じうる。

探究の理論は、習慣が進化する仕方についての理論として理解で きる。パースは科学の進化を生物の進化論とのアナロジーで説明し ているが、そこでアブダクションが生物の生殖における変異に相当 すると考えている（CP 7.38）。後期定式化に示されているように、 A という仮説を導くアブダクションは、その第二行に表される習慣 に媒介されているが、A を生むためには、この習慣がすでに A を含 んでいなくてはならない (CP5.189)。しかし驚くべき事実の観察の 
前からAがあるのなら驚くことはない。だからアブダクションは、 習慣の変化を伴う。ただしその変化は暫定的なものであり、演繹的 に明確化され、帰納的に検証されるまでは確定しない。この探究の プロセスによって習慣は進化する。

\subsection{3 カテゴリーと推論形式}

パースの哲学の全ての基底に、彼の「カテゴリー」(category）論 がある。パースは三つのカテゴリーによってすべての存在のあり方 を分類している。すなわち、

一次性 (firstness) : 何かそれ自体であって、他のものと関係を持た ないようなもののあり方

二次性 (secondness)：何か他のものと関係しているが、いかなる 第三のものを含まないようなもののあり方

三次性（thirdness）: 第一のものと第二のものを互いに関係づける ようなもののあり方（CP 8.328）

それぞれの形式的定義は、次のような質的定義に対応している。 つまり一次性は、「積極的な質的可能性の存在様式」、二次性は「現 にある事実の存在様式」、三次性は「未来の事実を支配するであろう 法則の存在様式」である (CP 1.23)。「可能性」(possibility)、「質」 (quality) や「感じ」(feeling) が一次性に、「事実」(fact)、「強 制」(compulsion)や「抵抗」(resistance) が二次性に、「習慣」(habit)、 「法則」（law）や「媒介」（mediation）が三次性に含まれる。

推論形式に関しては、アブダクションが一次性、演繹が二次性、 帰納が三次性に対応するという（CP 2.96）。さらに前期理論におい ては、小前提を一次性、結論を二次性、大前提を三次性に対応させ ている (CP 2.712)。つまりそれぞれの推論の結論のカテゴリーが、 それぞれの推論形式のカテゴリーに一致すると考えるのである。

後期理論においてパースは三段論法の形式に拘ることを止める (CP 2.102)。しかしながら、1）三つの推論形式を三項構造で理 解すること、2）その三項の入れ替えによって三つの推論形式を定 義すること、3）その三項を一次性、二次性、三次性のカテゴリー に対応させることは維持されたと考えられる。実際パースは演繹と 帰納については明示的に、「演繹的推論においては、三次性の作用に よって、一次性から二次性がもたらされている」「帰納的推論では、 一次性とそれに続く二次性とが三次性を生みだしている」と述べて いる ${ }^{20)}$ 。同様にアブダクションは二次性と三次性から一次性を生む はずである。よって推論の三形式は図 2 のように図式化できる。

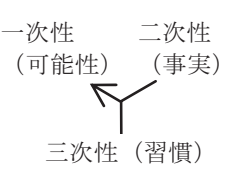

アブダクション

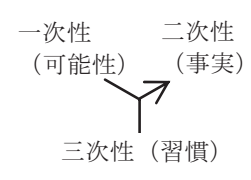

演繹

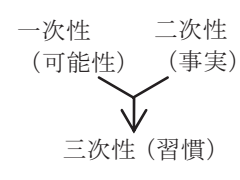

帰納
図 2 カテゴリーと推論の三形式

後期のアブダクションの定式化に関して言えば、第一行が二次性、 第二行が三次性、第三行が一次性に対応している。第一行の「驚く べき事実」は外的な強制であり、二次性のカテゴリーに含まれる。 次に第二行「しかしもし A が真であれば C は当然のことであろう」 は、アブダクションを媒介する習慣、つまり三次性を表している。 $\mathrm{A}$ は $\mathrm{C}$ から直観によって得られるのではなく、 $\mathrm{A}$ と $\mathrm{C}$ を結びっける ものの見方（習慣）によって媒介されているのである。そして第三
行に表されるアブダクションが生んだ仮説 A は、可能性として暫定 的に採用されるに過ぎないという意味で一次性である。

アブダクション、演繹、帰納の循環によって習慣は進化する。ア ブダクションの契機となるのは、驚くべき事実、つまり演繹された 予想と一致しない事実（二次性）である。アブダクションは驚くべ き事実を説明する仮説を可能性（一次性）として生むが、そのとき 習慣（三次性）の暫定的変化を伴う。演繹は、観察される事実の予 想 (二次性) を仮説の帰結として導く。帰納は予想と一致する事実 から仮説の妥当性を検証する。これは、アブダクションによって暫 定的に変化した習慣（三次性）が確定される段階である。

このアブダクション、演繹、帰納と一次性、二次性、三次性の関 係をまとめて図 3 のように描くことにする。カテゴリーの観点から 見るとき、三つの推論形式を最も原理的な形で理解することができ るだろう。この理解に基づいて後では、スケッチの描画など純粋な 心的プロセスではないものも、この推論形式によって捉える。

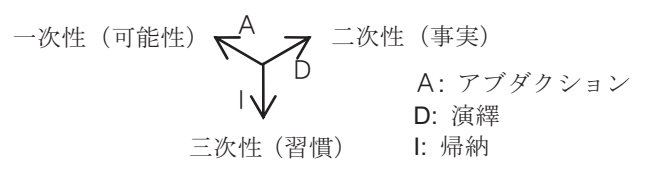

図 3 カテゴリーと推論の三形式

\section{4. パースの探究の理論の設計プロセスへの適用}

ここでは、パースの探究の理論を設計プロセスに適用し、設計プ ロセスのモデルを構築する。そこで関連が深く示唆的な既往研究と してD.アンダーソン（D. Anderson）の議論を参照する。彼はパー スの探究の理論を芸術に適用している 211 。芸術は設計と同じではな いが、科学との対比において設計と類似した特徴も持つと言える。

\section{1 アンダーソンによる芸術の方法論への適用}

アンダーソンはパースの理論の芸術への適用として、芸術的アブ ダクション、芸術的演繹、芸術的州納の概念を提出している。

科学的アブダクション（科学的探究における仮説の生成）は「驚 き」から始まり、それを説明する理論を与える。一方で、芸術的ア ブダクションは「不安」（uneasiness）から始まる。不安とは、あ るべきものの久如の感じである。芸術的アブダクションは「新しい 感覚の質」を表現することによって、この欠如を埋める。アンダー ソンはそこでの「想像」（imagination）、「観察」(observation)、「受 容性」（receptivity）の重要性を指摘している ${ }^{22) 。 ~}$

芸術的演繹は、アブダクションで得られた観念を何かに投射する ことで明確化（precide）する。

芸術的アブダクションによって得られた観念は、芸術的演繹を経 て、「審美的観照」によって試験できるものになる。芸術的帰納はこ の試験ないし評価の段階であり、演繹で明確化された作品が審美的 に良いものかどうかが問われる。

\section{2 探究としての設計プロセスのモデルの構築}

設計プロセスとは、何を実際に作るべきかが不確定の状態つまり 疑念から、確定した状態つまり信念へと至る、探究であると考えら れる注5)。探究としての設計プロセスは、大まかに言えば、アンダー ソンが述べた芸術について適用したのと同じような仕方で、アブダ クション、演繹、そして帰納によって構成されると考えることがで きる。つまり、アブダクションはアイデアを生み、演繹がそれを具 
体的なデザインへと明確化し、帰納が評価する。探究は循環的な構 造を持つ。探究としての設計は、アブダクション、演繹、帰納を一 巡して終わるのではなく、何度も往復しながら進展することになる だろう。アイデアは科学的探究における仮説に相当するが、アンダ ーソンが芸術について述べたのと同様に、設計においても、事実を 説明すると言うより、事実へと具体化されるべき仮説である。アン ダーソンは「驚き」と言うより「不安」が芸術的アブダクションの 契機となるとしている。しかし重要なのは「驚き」であれ「不安」 であれ、疑念を生む外的要因としての二次性がアブダクションの契 機となるということである。

設計が扱うのは現実の世界 (事実) だけでなく、設計者が設計に おいて構築する仮想的な世界であると言える。これを「設計世界」 （design world）と呼ぶ注 4)。設計世界は、可能性と事実の両方の性 質を持ったものとして考える必要がある。つまり設計世界は事実 (二 次性）についての可能性（一次性）であるが、一方で設計の中で設 計世界はそれ自体仮想的な事実 (二次性) として経験される。そこ で、アイデアやコンセプトは、この設計世界についてのさらなる可 能性（一次性）となる。また、ショーンが重視する「反省」は、自 らの習慣（三次性）についての仮説の生成であると考えられる。こ うして図 3 の三項関係が多層的に重なることを考えると、探究とし ての設計プロセスのモデルは図 4 のように描くことができる。この 図式は相対的なものであって、原理的にはどの方向にも無限に拡張 できるし無限に分割できるだろう。しかし本論で三つの三項関係に 注目するのは、この範囲で多くの設計プロセスが理解できると考え るからである。

\section{3 探究としての設計プロセスの要素 \\ 1 ) 事実}

設計プロセスにおける「事実」は、スケッチ、模型、コンピュー ターのスクリーン映像、書かれた文字、発話された声、与条件（ク ライアントが要求を述べた言葉など）、課題書類、敷地、街、建材、 人間などの、現実に存在する事象である。「事実」についての解釈は、 「設計世界」や「アイデア」に含まれる。たとえば、与条件やスケ ッチは「事実」であるが、それをもとに解釈された設計条件やデザ インは次に述べる「設計世界」に含まれる注 6)。

\section{2 ) 設計世界}

「設計世界」は、通常「デザイン」と呼ばれるような、設計され ている対象（対象の関係、属性を含む）の他、設計者が事実をもと に構成した設計条件、プログラムなどを含む。「設計世界」は「事実」 と異なり、設計が扱うべく再構成された想像上の世界である。しか し、この想像の上ではあたかも事実であるかのように、設計者に強 いられる。たとえば、まだ建てられていない建築のデザインについ て、この階段は頭を打つといったことを設計者は想像の中で経験す ることがある。設計者は「事実」を読夕取って、「設計世界」を制作 する (アブダクション)。一方で、「設計世界」をスケッチなどの「事 実」に具体化する (演繹)。

\section{3) 習慣 1}

この演繹やアブダクションを媒介する「習慣 $1 」$ は、「事実」から 問題を構成する「フレーム」のほか、図面の見方や描き方を含む。 たとえば、建築の断面図からそこに描かれたデザインを読み取る能 力や、デザインを鳥瞰図に描く能力である。

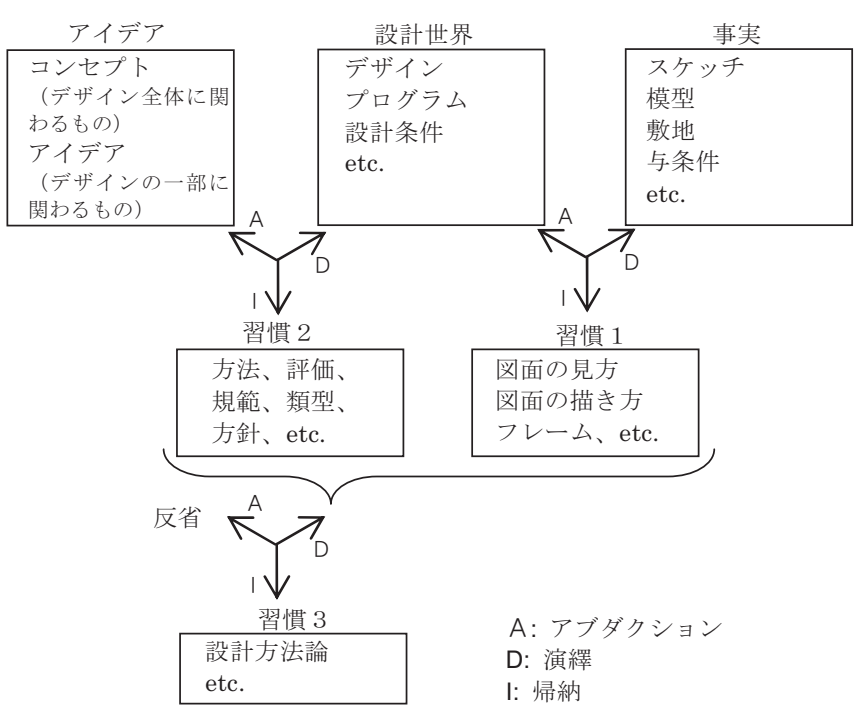

図4 探究としての設計プロセス

\section{4) アイデア}

デザインは通常、なんらかの「アイデア」の具体化（演繹）とし ての側面を持つ。一方でこうした「アイデア」は「設計世界」(たと えば設計条件）から発想されている(アブダクション)。「アイデア」 は「設計世界」とは異なり、仮想的な世界の中で強いられるもので はない。「アイデア」のうち、とくにデザインの全体に関わるような （たとえばデザインの全体を説明するような）「アイデア」は「コン セプト」と呼ぶことにする。一つの設計プロセスの全体は「コンセ プト」を仮説とした探究として見られる。問題と解決という観点か らは次のように言える。すなわち、「設計世界」を問題としたとき、 新しい可能性（「アイデア」）が解決として生成されるが、この解決 を「設計世界」へと明確化することでデザインを生成すれば、それ じたい新たな問題となる。ただし、後で述べるように、「設計世界」 の孕む問題に気付くためには、多くの場合、「設計世界」を「事実」 （スケッチや模型）へと明確化することが必要となるだろう。

\section{5 ) 習慣 2}

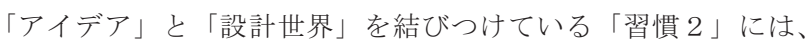
「アイデア」からデザインを導く方法の他、評価、規範、類型、方 針、などが含まれる。たとえば、設計者は「コンセプトによって説 明できるようなデザインが良い」といったような、しばしば暗然的 な規範を持っており、それに基づいてデザインを進めている。

\section{6 ）反省}

設計者は、「習慣 $1 」 や 「$ 習慣 2 」について考え、それを変更する ことができる。自身の習慣についての仮説が「反省」だと言える。

\section{7 ) 習慣 3}

この反省は何らかの絶対的な基盤の上でなされるのではなく、そ れもまた習慣の上でなされている。このメタの習慣を「習慣 $3 」$ と している。ここには設計方法論も含まれる。というのも、設計方法 論は設計方法についての理論であり、この理論が、それに基づいて 設計が行われるような習慣となっている場合、それは習慣（設計方 法）についての習慣となっているからである。習慣 3 」によって「習 慣 2 」を演繹的に決定していることが、設計プロセスをコントロー ルすることになる。 


\section{5. ケーススタディー}

ここでは構築したモデルに基づいて設計プロセスの事例を分析し、 それによって設計プロセスにどのような構造が見いだされるのかを 示す。こうして実際に事例の分析に用いることによってモデルの意 味が明確化される。設計プロセスを理解するための観点を提供する ことが設計プロセスのモデルの価值だと考える。このケーススタデ イーの目的は、設計プロセスの一般的な傾向を判定することではな く、提案したモデルに基づいて設計プロセスを理解するための観点 を見いだす試みを通して、提案したモデルの意味を明確化し評価す ることである。

\section{1 事例}

具体的な設計プロセスの事例を得るために、「設計実験」(design experiment）を行った ${ }^{23)}$ 。設計課題を 20 人の被験者に与えた。課 題の内容は、京都の中心部の職住共存地域に敷地をとった住宅設計 であり、「コミュニケーションのあり方を考慮する」ということを条 件とした。被験者は寸べて建築学科の学生である。それぞれを被験 者 1 、被験者 $2 \cdots$ 被験者 20 と呼ぶ。被験者には考えたことをなる ベく声に出してもらい、その設計プロセスをビデオカメラおよび IC レコーダで記録した。この方法 (発話プロトコル法 ${ }^{24)}$ ) によって設 計プロセスの詳細なデータが得られる。制限時間は 40 分とし、設 計後、被験者に対し 15 分程度のインタビューを行い、プロセスを 確認した。なお、本実験における被験者は学生でありプロの建築家 ではないが、学生にも熟練した専門家に見られるようなプロセスの 原型は見られるはずだと考えている。

\section{2 事例分析}

提案したモデルによって事例を分析する。図 5 は、被験者 19 の 設計プロセスの開始後 5 分から 11 分についての分析である。この 図で、灰色の楕円のうち空白のものは、灰色の線でつながれた上の 楕円の内容を引き継いでいることを表している。

\section{3 設計プロセスの局面}

設計プロセスにおける諸局面は図 6 のように、提案したモデルに おける、アブダクション、演繹、帰納、あるいはそれらの組み合わ せとして理解できる。この図は、以下に説明する個々の設計プロセ スの局面を示寸図を重㸚合わせて描いたものである。

\begin{tabular}{|ll|}
\hline 1) & 問題設定 \\
2) & アイデアの生成 \\
3） & アイデアから \\
& デザインの展開 \\
4） & ザインの評価 \\
5） & アイデアの転換 \\
6） & プロセスの制御 \\
7） & 反省 \\
8） & デザインの正当化 \\
\hline
\end{tabular}

図 6
6 設計プロセスの諸局面

\section{1 ) 問題設定}

設計の初期、つまり課題を読む段階や読んだ直後に、全ての被験 者は与えられた課題を再構築し問題を設定した注 6)。これは設計課題 からのアブダクションによる設計世界の構築である (図 7 )。もつと

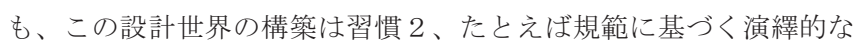
決定という面も持ちうる。問題設定は設計を通じて変更されうる。

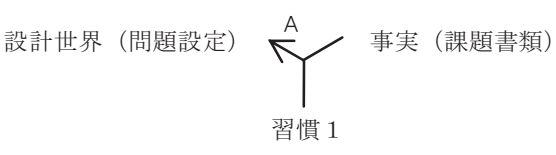

図 7 問題の設定

\section{1-1）制約の追加}

問題設定において、多くの被験者は制約を追加していた。例えば、 被験者 13 は開始後 1 分でこう発話している。「でも書斎はいるわな 書斎はいるよな。書斎。書斎とリビング。ダイニングキッチンがあ って、まあ子供部屋はあってもなくてもいいかな。…

制約の追加によって設計世界は具体化される。具体化された設計 世界は、アイデアを生むアブダクションの契機になりやすくなると 考えられる。

\section{$1 － 2$ ）共有されたフレーム}

問題設定は特定のフレーム、つまり事実（課題）の捉え方に基づ いて行われる。今回の実験において多くの被験者に共有されたフレ 一ムが存在することが見て取れた。それは、寝室やキッチンが必要 だという常識的なものだけではなく、特定の領域において共有され ている問題意識のようなもの含む。つまり、与えられた課題はコミ ユニケーションを考慮するということであったが、それに対してほ とんどの被験者は、周辺住民とのコミュニケーションを積極的に誘 発させるという問題を設定した。はっきりとそうでない被験者は外 国人留学生である被験者 14 一人であって、彼はむしろ、家族内の コミュニケーションをいかに制限するかということに注意を向けた。

\section{2 ) アイデアの生成}

設計者は特に問題設定からのアブダクションによってアイデアを 生みだす (図 8 )。

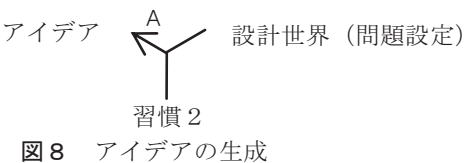

\section{2－1）プライマリージェネレーター}

多くの被験者は、問題設定をしながら、あるいはした直後にアイ デアを出していた。J.ダーク（J. Darke）はこのように設計者が設 計の初期に生みだすアイデアを「プライマリージェネレーター」 (primary generator) と呼んでいる 7)。例えば被験者 19 は開始後 2 分に「庭」のアイデアを生みだしている。多くの被験者は開始後 数分で何らかのアイデアを生みだしている。

\section{2-2）想像、観察、受容性}

アンダーソンは芸術的アブダクションにおける想像、観察、受容 性の重要性を指摘していた。設計においてもそれは言えるだろう。 このうち想像と観察は設計世界を明確化することに関わる。例えば 被験者 19 は、パーティーやバーベキューをすることを想像してい た。ここで、パーティーをすることを発想するのはアブダクション だが、その様子を想像するのは演繹である。

また被験者 10 は課題書類の敷地図を観察し、隣接寸る家屋との 隙間の空間に注目していた。こうた観察はアブダクションである。 注目すべきは、必ずしも図面に意図されたのではないもの(この場 合は隙間）を設計者は発見できる点である。設計世界はこうした想 


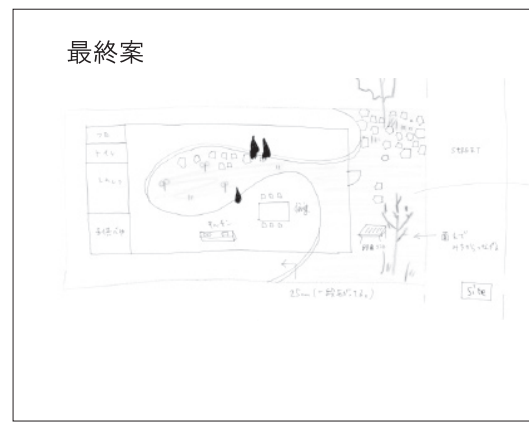

発話プロトコル

んんとあと十分，あと五分くらい考えようかな. も時間ないな一.ん一，んん．これやだな一. 流行 りっぽいなー. かわいいけどね. かわいいのかなあ? んんなんかこういうのがコンペにかつんだよねー. まあいいやそのニって.あとは,

セットバックして，めっちゃおっきい木を植えると か. すっごいセットバックして…, めっちゃおっき い木があって，大きな栗の木の下でつみたいな.し たら，なんかこっち側からこっち側なんかいっちゃ いけなそう，っていうか，なんか面一なことが重要 な気もするよね. 通りから, ここまでは, なんか面 一っぽい感じになってるんだけど，ここをそういえ ばー段上がってたら，なんか向こうにいっちやいけ ない感じがしそう，だね．面一。

いいや. そうしたらここが，コミュニティースペー ス?あ, でもなんかそうしたら, 断面で, こう道路 があって，敷地があって，なんかここさえ面一だっ たら,なんか石睤みたいな感じになってて, そした ら、ここを跨いだらおうちみたいのがあってもかわ いいのか. んんでも, どうなんだろう？んん. あと はどうこの人たちが住むか、コミュニティーばっか 考えちやってるけど,

家族ん中か，家族ん中のコミュニティーか，住民と 家族のコミュニティーっていうのはでもまあこれだ いたい考えるけど，家族の中のコミュニティーは， そっか庭がヌルーってなんかちょっとなっててもい いんかな. なんかこうだったら靴脱がないから立ち 話しやすそう。でなんかここが一段あがってて，な んか平屋がいいな一, 何となく. 七メーターかけ十 五メーターって結構，広いか，結構広いね，ん一ん んん. ん-.

家族の中のコミュニティー，なんかここでこう，な んか,ここがなんかちっちやい縁側みたいになった らかわいいのかなあ. おしやれー。んーんん.なん かこのへんのディテールが思いつかないな.なんか すぐガラスボックスみたいになっちやうのがやだ な一、んんー、どうしょう.

ん一, 家族の中. 家族の中. でも, この二棟になっ てるやつだったら… あそっか, これってでも, 子 どもちっちやいから, 子ども向こう側にやるとかし たら，結構微妙なんか，ああ一なんかコミュニ ティーっぽいのやりたかったんだよね.ややばい時間 ないな.んんでもコンセプトは路地庭みたいな. 庭 がやっぱ.

立ち話がコミュニティーなんだよな，近隣住民と． 話, できるとこ，で，それがかつバーベキューでき たりみたいな. $\cdots$ キューとか, ガーデンパーティー みたいな.につながるから，これが住民と家族、で， 家族の中のコミュニティーをなんか決めないといけ ないんだよね、したら形になんないってことだよ。 んーん，んんと.でもたぶんこども大好きだから， なんか子供もまだちっちやいしなあ，子供のための 家. なんだけど, なんか，大きくなっても， なんか愛着がわくような. はあ一.ん一んん一. ど うしたらいいかな一. でもこうしたときに, 絶対に,

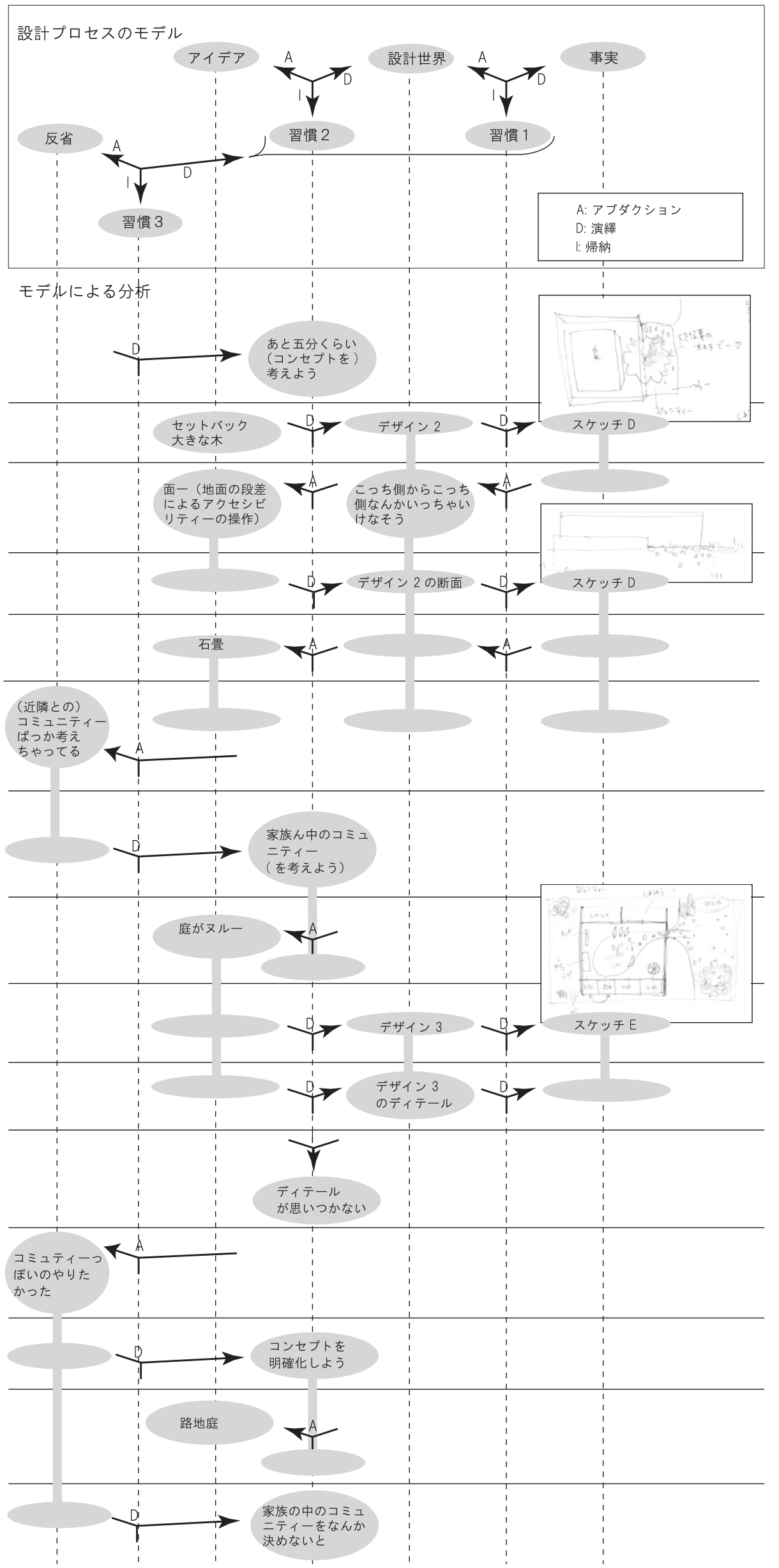

設計プロセスのモデル 
像や観察によって明確化されると、アブダクションの契機になりや すくなるだろう（図 9 )。

アイデア
習慣 2
想像

図 9 想像と観察

受容性はアイデアを直ぐに判断せずに、とりあえず試してみると いうこと（それに基づいて設計世界を明確化してみる演繹的段階） に関わる。例えば被験者 17 は 11 の区別できるデザインを生みだ している。そこにはあまり芳しくないアイデアから意外と良い結果 が生まれることへの期待があるのだろう。実際、最終案の原型とな った「ペントハウス」のアイデアも、課題であるコミュニケーショ ンに関係ないということから、ためらいがちに出された。

\section{$2-3$ ) 共有された解決方法}

コミュニケーションを積極的に誘発させるという共有された問題 設定に対する解決方法もまた、多くの被験者で共有されていた。つ まりそれは、内外を媒介するような、あるいは半公共的な、「庭」を 用いるというものである。被験者 20 人中の実に 8 人が「庭」を重 要なアイデアとして採用していた。

\section{3 ) アイデアからデザインへの展開}

アイデアを評価するためには、まずそれを具体的なデザインへと 明確化されなくてはならない。この明確化のために、設計者は多く の場合、デザインを表すスケッチなどの外的表象の助けを借りる必 要がある(図 10 )。

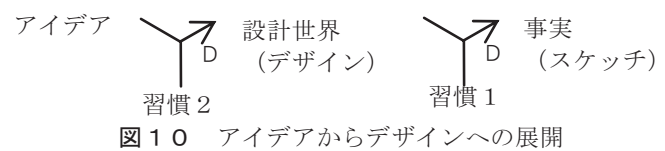

デザインへの具体化の方法は一様ではない。例えば、被験者 14 はヒエラルキーというアイデアから、水平的な階層構造、垂直的な 階層構造、あるいは入れ子状の階層構造をもったデザインを生んで いる(図 1 1 $)$ 。

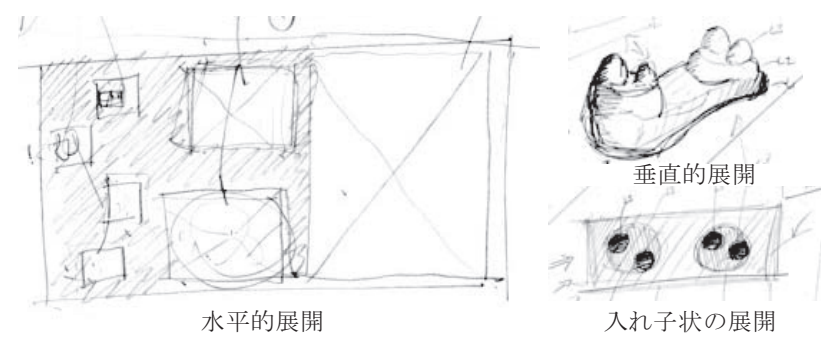

図11 アイデア「ヒエラルキー」からデザインへの多様な展開

探究が循環的であるという意味では、演繹がアブダクションの準 備となるという点に注目しなくてはならない。アイデアはデザイン へと具体化されることによって、予期せ姓質を孕むようになる。 たとえば被験者 14 は水平的な階層構造をもったデザインにおける、 余白の部分（斜線が引かれている）の空間的関係に注目していが、
これは階層構造というアイデア自体には含まれない。 アイデアからデザインへの展開の方法にどのようなバリエーショ ンがあるのかは、知識として習得できるだろう（習慣 2 )。デザイン の明確化を助ける外的表象の制作においては、スケッチを描く、C A Dを操作する、などのスキルが必要とされる（習慣 1 )。

\section{4 ） デザインの評価}

アイデアは具体的なデザインへと明確化されることによって評価 できるようになる (図 12 )。評価が不満足なものであるとき、それ はアンダーソンのいうアブダクションの契機としての「不安」を感 じる段階でありうる。当然かもしれないが、検討中の案に対する不 満足が、新しい案を生むきっかけとなる。不安を生むために、22 ）で述べた想像や観察が必要であろう。例えば実際に人が生活す ることを想像すると、思い通りにならないことが分かったりする。 実験では表 1 のうな発話の後に大きな転換が見られた。

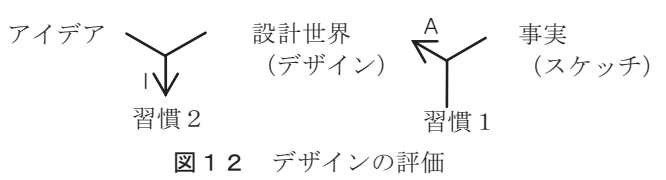

表 1 「不安」の表明

\begin{tabular}{|c|c|}
\hline $\begin{array}{l}\text { 被験者 } 1 \\
\text { 被験者 } 3 \\
\text { 被験者 } 5 \\
\text { 被験者 } 10 \\
\text { 被験者 } 12 \\
\text { 被験者 } 17 \\
\text { 被験者 } 19\end{array}$ & $\begin{array}{l}\text { これだと全然よくないのかな } \\
\text { ここか、こっちかな、したらもうキーのゾーンがだめだし } \\
\text { これならもっといいデザインがあると思うけれどなあ } \\
\text { 一階がちょっとパブリック性が強すぎるかも } \\
\text { あんまりオープンな庭でそんなねーいろいろ活動しないよ } \\
\text { なんかつながってないと意味ないしなあ } \\
\text { 流行りっぽすぎるきもするなあこれ。やだなあちょと }\end{array}$ \\
\hline
\end{tabular}

\section{5 ) アイデアの転換}

アイデア（あるいはコンセプト）が設計の中で転換することがあ る。このとき問題設定まで変更されることもある。コンセプトの転 換は多くの場合、すでにあるデザインに意図せぬ性質を見つけるこ とによって生じる（図１３）。

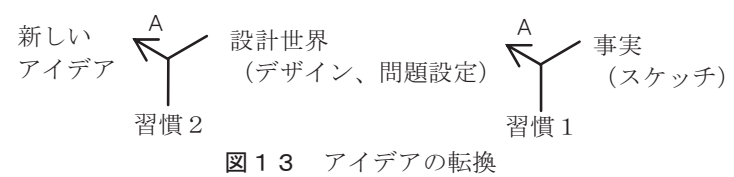

意図せぬ性質の発見はしばしばすでに描かれたスケッチなどの外 的表象を新しい仕方で見ることによって生じる。例えば被験者 1 は 「居場所」が「穏やかにつながる」ことを意図した S 字型平面のデ ザインを考えていた (図 14 左)。開口を空けるとエントランスから リビングが直接見えてしまうことについて不満（前述の「これだと 全然よくないのかな」）を述べていた。しかしこのとき、開口を空け ることによって、外から見ると内部と外部が交互に重なり合うこと (後に被験者は「フレーム」と呼んでいる）に気付く（図１４右）。 そしてむしろこのことを最終的なコンセプトとしたのである。また、 被験者ははじめ近隣とのコミュニケーションのあり方について考え ることを諦め、家の中のコミュニケーションのあり方しか考えない 
ことにしていたのだが、「フレーム」は近隣とのコミュニケーション のあり方についての提案になっている。このように問題設定も変更 されている。

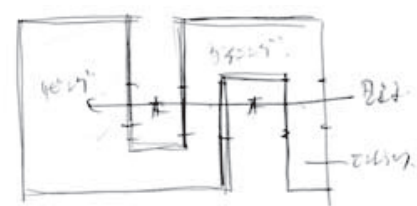

図 14 S 字型平面のデザイン

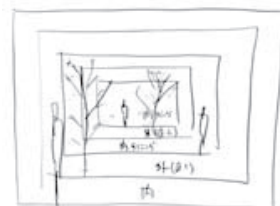

(左) と「フレーム」(右)
被験者 5 は、表 1 の発話「これならもつといいデザインがあると 思うけれどなあ」の後、それまで平面図として描かれていた図面 (図 15 左）を断面図としてみなしている。それによって生じたデザイ ンが最終案となっている(図 15 右)。
図 15 先行する平面図 (左) と最終案の断面図（右）

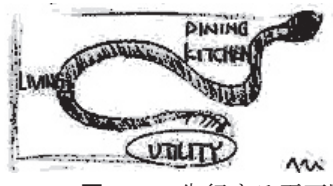

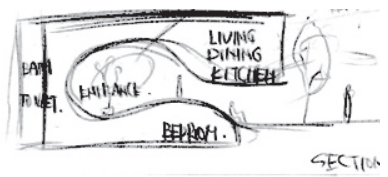
GEC
この段階に注目すると、被験者 5 は先行するデザインが「比喻的 に言ったら」何かを自らに問いかけ、蛇」などの候補を述べている。 そして最終的に比喻として「子宮」を採用し、その直後にこのスケ ッチを断面図とみなすことにしている。ここで「比喻的」観点から スケッチを見るためには、建築の平面図としてのみスケッチを見る ことを止めなくてはならない。だから、被験者はメタファーを用い ることによって、スケッチを見る見方（習慣 1 ）に介入していると 言えるだろう。

\section{6 ）プロセスの制御}

設計者は、設計の状況に合わせてやり方を考えて実行する。発話 において、今から何をするかについての宣言が見受けられる。この 場合はプロセスが意図的に制御されていることが分かる（図 16 )。

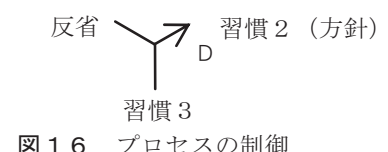

例えば被験者 19 は先行するデザインについての不満を述べたあ と、「断面で考えてみる」ことを宣言し実行している。それまで平面 形状で考えていたわけだが、見方を変えることでデザインの他の面 が明確化される。

\section{7 ) 反省}

反省は、これまでのプロセスのレビューや批判といった形で、自 らの習慣についての仮説を生みだす（図 17 )。

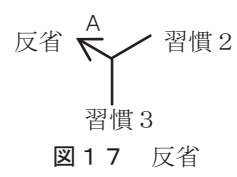

例えば、被験者 6 はこう発話している。「話を整理しよう、今考え
ていることは、一階は、人が、いつ来ても大丈夫なところ。人をも てなす。で、人がこう来たら…このようにして反省はコンセプト を明確化することにも関わる。

\section{8 ) 正当化}

一般的に設計者は最終的には自らのデザインについてなぜそれが 良いのか説明する。つまりデザインは正当化されなくてはならない。 デザインを説明する論理を生みださなくてはならない。この論理の 生成はアブダクションだといえる（図１８）注7)。

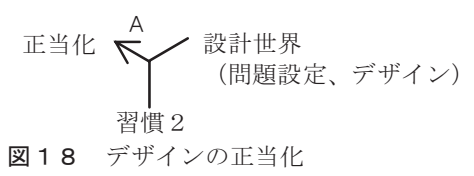

\section{4 設計プロセスにおける習慣と創造性}

アイデア、設計世界と事実が習慣によって媒介されているという ことは決定的に重要である。被験者によって類似した／異なるアイ デアを出すのは、類似した／異なる習慣を持っているからだといえ る。コミュニケーションを考慮すると言う課題に対して、被験者 1 4 だけがコミュニケーションを制限することを問題として設定し、 他の被験者はコミュニケーションを誘発させることを問題として設 定したことは、被験者 14 が外国人留学生であり、異なる習慣を持 っているということと無関係ではないはずである。

設計プロセスにおける習慣には、建築の類型・様式さらには、規 範・価值観・イデオロギーといったものを含むことができる。今回 の事例では、庭によって外部と内部を結ぶという建築の形式や、コ ミュニケーションを誘発すべきだという問題意識が多くの被験者に 共有されていた。前者は類型、後者は規範に関わり、この場合強く 結びついている湦8)。実際に設計は、染意性を免れえない、こうした 習慣に基づいて行われる。しかし、こうした習慣は、従来の設計プ ロセス研究においては外的なものとして捉えられがちであった。と いうのも合理的問題解決としての設計という見方は、恣意的な価值 観や様式とは独立した、あくまで客観的な行為として設計を理解し ようとするからである。しかし創造性とは習慣の変化を生みだすも のであり、特に革新的な創造性は社会的に共有された習慣の変化を 生みだす。設計プロセスの創造性の研究にとっては、このような習 慣の変化の機制が重要なテーマとなる。

\section{5 アブダクションの契機を与えるものとしての演繹と帰納}

アイデアを生成するアブダクションにおいて、習慣はアイデアを 一義的に決定しているのではなく、むしろ習慣からの逸脱がありえ る。とくに創造的なアイデアとは、習慣から逸脱するものである。 なぜなら、そうでなければ習慣の変化を生みだすことはないから。 アブダクションそのものは十分コントロールできない、予測不能性 を孕んだものであることを認めなくてはならない。しかし設計の創 造性は演繹・帰納を加えた探究の全体に拠るものであり、そこで演 繹・帰納がアブダクションの準備となる重要な局面となる。演繹に よって設計世界や事実に向かい、帰納によってそれを評価すること が、アブダクションの契機となる。アブダクションと異なり、演繹 や帰納は設計方法論によって意図的、直接的に左右できる。今回の 実験でアイデアの転換は、多くの場合、スケッチを描き、そこに意 図せぬ性質を見いだすときに生じていた。 


\section{6. 結論と今後の課題}

本論ではパースの探究の理論に基づいた設計プロセスのモデルの 構築を試みた。このモデルは、我々が設計を既存の習慣からしか始 めることができないことを受け入れつつ、設計の習慣がどのように して進化しうるのかを探究するための可謬主義的モデルである。本 論はこのモデルを、アブダクション、演繹、帰納によって結び付け られた三項関係からなるものとして構築し、それに基づいて具体的 な事例を分析した。このモデルによって、設計プロセスを理解する ための多様な観点が得られることが示された。また、我々がどのよ うな習慣に基づいて設計をしているかについて多くの示唆を得た。

本論ではモデルの全体像を示すことを試みた。より詳細な研究は 今後行わなくてはならない。「アイデア」、設計世界」「習慣」とい った領域について、さらに内部の構造を考えたい。すでに著者はパ ースの記号分類による設計プロセスの分析を行っているが 23)、記号 分類と合わせて考えることが助けになると考えている。

今回の実験は特殊な条件の下で行われている。設計時間の短さは、 問題を再設定したり、反省したりする時間を与えなかったかもしれ ない。またそこでの「事実」は、ほぼ課題書類とスケッチに限定さ れており、他の「事実」へと向から機会が与えられていなかった。

こうしたことは設計の可能性を大きく制限したかもしれない。実際 の設計では、スケッチだけではなく、模型、人間、都市といった「事 実」へと向からこともまたアブダクションのきっかけとなりうる。 したがって他の設計事例についても検討すべきだろう。

今回、設計プロセスの社会的側面には焦点を当てることがなかっ た。今後はこれを理解すべく本論のモデルを展開したい注 10)。

※本研究は、平成 19 23 年度科学研究費補助金学術創成研究「記号過程を内 包した動的適応システムの設計論」(研究代表者: 椹木哲夫)の一部として 遂行したものである。

\section{注}

注 1)「合理的問題解決としての設計」はショーンの用語であり、リッテルの 用語では「第一世代のシステム・アプローチ (systems approach of the first generation)」に対応する ${ }^{4)}$ 。これに代わる「第二世代」のアプローチとし てリッテルは「論争的プロセス」としての設計という見方を示した。

注 2) CP は参考文献 15)，16）, 17)の Collected Papers of Charles Sanders Peirceの略記であり、数字は巻と節を示す。この場合は第 2 巻 96 節を意 味する。

注 3）厳密には、驚きには二通りが考えられる。「驚きにもまた、能動的なも のと受動的なものがある; 一前者は予想と積極的に矛盾するものを知覚す る時であり、後者は積極的な予想は持たずにただ突飛なことへの疑念に久 如していて、何かとても予想外なことが起こる時である」（CP 8.315）

注 4) 絵画や彫刻などの場合、アイデアを事実 (作品) へと明確化し(演繹)、 作品そのものが評価（帰納）されうる。しかし設計においては、描かれた スケッチがそれ自体として評価されるのではない。それが表象するもの、 つまり、設計者が構築しつつあってまだ現実には存在しない想像上の世界、 つまり設計世界が評価されるのである。なお、「設計世界」の概念はショー ンに由来する。ショーンの言う設計世界とは、「設計者が設計において入り 込んで住む環境である。それは物、関係、および質の特定の配置を含み、 設計知識のための支持的環境 (holding environments）として働く。」25)

注 5）本論のモデルは探究の持つ他の側面も区別できる。つまり、設計はとく に習慣 2 のうちの、特定のデザインとそこに具体化されたコンセプトにつ いての評価の形成に関わる探究だと言える。しかしそれだけではなく、複 数の設計世界に適合する一般的な方法、原則やタイプの確立のプロセスと して見ることもできる。あるいは、習慣 1 の図面の見方や描き方を形成寸 るプロセスとして見ることもできるし、習慣 3 の設計方法論を形成するプ ロセスとして見ることもできる。

注 6) 設計の与件と設計条件は区別されるべきである 26)。与条件が設計条件
として妥当であるとは限らない。設計者は、与条件を踏まえて、設計プロ セスの中で設計条件を構築する必要がある。

注 7）最初に問題設定を行わないプロセスも可能ではある。つまり、課題と無 関倸にデザインを展開し事後的に課題に当てはめることもできる。これは、 Finke らのいう”function follows form”アプローチである。27)

注 8）被験者がデザインを正当化するタイミングには大きな違いが見られた。 正当化を設計の初期に行うか後期に行うかの違いは B.ローソン（B. Lawson）による「問題に焦点を結ぶ戦略」(problem focused strategy) と 「解に焦点を結ぶ戦略」(solution focused strategy) の区別とも関わる7)。

注 9） 5 章の「問題設定」では、この問題意識を習慣 1 に含めたが、問題設定 を習慣 2 亿基づく演繹だと見れば、むしろ習慣 2 に含められる。

注 10）設計の社会的側面を捉えるためには、「主体」、「身体」「他者」、そし て「規範」といった概念が鍵になるだろう。

\section{参考文献}

1) Bamford, Greg: From analysis/synthesis to conjecture/analysis: a review of Karl Popper's influence on design methodology in architecture, Design Studies, 23, pp.245-261, 2002

2）伊東邦武：パースのプラグマティズム，勁草書房，1985

3）太田利彦：設計方法論、丸善、1981.

4) Protzen, Jean-Pierre, and Harris, David J: The Universe of Design, Horst Rittel's Theories of Design and Planning, Routledge, 2010 5) Schön, Donald A.: The Reflective Practitioner, Basic Book, 1982 6) Lawson, Bryan: How Designers Think, Butter Worth Architecture, 1988.

7）門内輝行：関係性のデザインーつくることから育てることへー，日本学術 会議人工物設計・生産研究連絡委員会設計工学専門委員会講演論文集, pp.1-8, 2004. 12 .

8) Schön, Donald A.: Problems, Frames and Perspectives on Designing, Design Studies 5 (3), 1984

9) Dorst, Kees, Dijkhuis, Judith: Comparing paradigms for describing design activity, Design Studies, Volume 16, Issue 2, pp. 261-274, 1995.

10) Brawne, Michael: Architectural Thought, The design Process and the Expectant Eye, Architectural Press, 2003

11)Anderson, Stanford: Architectural design as a system of research programmes, Design Studies, Volume 5, Issue 3, pp. 146-150, 1984.

12) Takeda, H., Abduction for design, in J. Gero and E. Tyugu eds., Formal Design Method for CAD, IFIP Transactions B-18, pp. 221-244, Elsevier Science Publishers B.V.,

13) Hartshorne, C. and Weiss, P. (eds.).: Collected Papers of Charles Sanders Peirce, Vol.1 2, The Belknap Press of Harvard University Press, 1978

14) Weiss, P. (ed.).: Collected Papers of Charles Sanders Peirce, Vol.3 4, The Belknap Press of Harvard University Press, 1980

15) Weiss, P. (ed.).: Collected Papers of Charles Sanders Peirce, Vol.5 6, The Belknap Press of Harvard University Press, 1978

16) Burks, A.W.(ed.): Collected Papers of Charles Sanders Peirce, Vol.7 \&, The Belknap Press of Harvard University Press, 1979

17) Kruijff, G. J. M.: Peirce's Late Theory of Abduction, Kluwer, 1998.

18) Fann, K.T.: Peirce's Theory of Abduction, Martins Nijhoff, 1970.

19）上山春平: アブダクションの理論, 人文学報第 45 号, 京都大学人文科学 研究所, 1978 .

20）パース、C．Ｓ．：連続性の哲学，岩波文庫，2004。

21) Anderson, Douglas R.: Creativity and the Philosophy of C. S. Peirce, Martinus Nijhoff Publishers, 1987.

22) Anderson, Douglas R.: The esthetic attitude of abduction, Semiotica, Vol 153-1/4, 2005.

23）山口純, 門内輝行 : C.S.パースの記号分類に基づく設計プロセスの分析, 日本建築学会計画系論文集，No.664，pp. 1111-1120，2011. 6 .

24）西村伸也，他：空間認識からみた設計の思考プロセスの考察一『視点』 による学生課題設計の分析一, 日本建築学会計画系論文集, No.455, pp.87-96, 1994. 1 .

25) Schön, Donald A.: Designing: Rules, Types and Worlds, Design Studies, 9(3), 1988.

26）日本建築学会建築計画委員会 : 設計方法論, 彰国社， 1974 .

27) Finke, Roland A., Smith, Steven M., and Ward, Thomas B.: 創造的認知 一実験で探るクリエイティブな発想のメカニズム，森北出版， 1999. 